\title{
A Wallachian Boyar in Emperor Joseph II's Court
}

\author{
Constanţa Vintilă-Ghiţulescu \\ New Europe College, Institute for Advanced Study/ 'Nicolae Iorga' \\ Institute of History, Bucharest, Romania \\ cvintilaghitulescu@gmail.com
}

\begin{abstract}
The article explores the intricacies of eighteenth-century cultural mediation through the eyes of Ianache Văcărescu, a high-ranking Wallachian boyar and a man of letters, entrusted in 1782 with the sensitive task of bringing the fugitive sons of the incumbent Wallachian ruler back from the Habsburg court in Vienna. Analyzing Văcărescu's account of the mission, I examine the nexus of luxury consumption, court civility, and social distinction, and the ways they were experienced and constructed the differences between European and Ottoman elite civility and cultural boundaries. In composing The History of the Most Powerful Ottoman Emperors, Ianache Văcărescu offered details about his place in a diplomatic network which spread across the Ottoman Empire and Central Europe.
\end{abstract}

\section{Keywords}

luxury - social status - Wallachia - Ottoman Empire - civility

\section{Introduction}

In the winter of 1782, Ianache Văcărescu, grand treasurer (vistier) of Wallachia, set out on a secret mission to the imperial court of Vienna. The two sons of the Phanariot ruling prince Alexandros Ypsilantis (1774-1782) had run away from home in search of adventure in the wondrous realms of Europe. At the time, Wallachia was under Ottoman domination, and the prince was directly appointed by the Sultan and integrated in the Ottoman administrative 
system. ${ }^{1}$ After the establishment of the Phanariot regime, princes and boyars preferred to avoid crossing the border to the west, although no official interdiction limiting their freedom of movement was ever pronounced. In other words, the roads and journeys of the political elite were directed for a century towards the Ottoman Empire. Braşov (German Kronstadt) and Sibiu (German Hermannstadt), in Habsburg Transylvania, were only temporary refuges in times of war, where boyar families might find a safe haven for a matter of months, or on occasion years, depending on the duration of the war and military occupation.

I am interested in how Ianache Văcărescu, ${ }^{2}$ in his capacity as a princely office-holder, Ottoman subject, and diplomatic agent, mediated between Istanbul and Vienna, using the knowledge and abilities that he had accumulated in the course of his meetings and travels. What kind of cultural intermediary was Ianache Văcărescu? ${ }^{3}$ In other words, can he be seen as a social actor who used his linguistic knowledge and his diplomatic relations to straddle and traverse the imperial borders? The advantage for such an enquiry lies in the fact that Ianache Văcărescu wrote about his diplomatic experiences, describing the journeys in which he was involved, and offering details about the people he met. All these details are to be found in his History of the Most Powerful Ottoman Emperors, which long remained in manuscript. ${ }^{4}$ Although

1 For more on this, see Christine Philliou, Biography of an Empire: Governing Ottomans in an Age of Revolution (Berkeley, 2011).

2 Also known by the diminutive Ienăchiță in Romanian historiography.

3 Recent contributions have demonstrated the role of diplomatic agents, interpreters, dragomans, and brokers in mediating contacts between Ottoman domains and Western Europe in the early modern period, see David Do Paço, "A Social History of Trans-Imperial Diplomacy in a Crisis Context: Herbert von Rathkeal's Circles of Belonging in Pera, 1779-1802," The International History Review 40, no. 5 (2018): 3-22; David Do Paço, Trans-Imperial Familiarity: Ottoman Ambassadors in Eighteenth-Century Vienna, in Practices of Diplomacy in the Early Modern World, c. 1410-180o, eds. Tracey A. Sowerby and Jan Hennings (London, 2017), 166184; Natalie Rothman, Brokering Empire: Trans-Imperial Subjects between Venice and Istanbul (Ithaca, 2012); and Francesca Trivellato, The Familiarity of Strangers: the Sephardic Diaspora, Livorno, and Cross-Culture Trade in the Early Modern Period (New Haven, 2009).

4 The full title of the history is: Istorie a prea puternicilor împărați otomani. Adunată şi alcătuită pă scurt de dumnealui Ianache Văcărescu dicheofilaz a bisericii cei mari a Răsăritului şi spătar al Valahiei. Începându-se în vremea prea puternicului împărat sultan Abdul Hamid I la văleatul bijretu 1202 şi mântuiroriu 1788 în Nicopoli a Bulgariei. Şi s-a săvîrşit în zilele prea puternicului impărat sultan Selim III la văleat 1794 şi 1208 în luna lui Şeval (History of the most powerful Ottoman emperors, gathered and put together in brief by Mr. Ianache Văcărescu, dikaiophylax of the great Church of the East and spătar of Wallachia. Begun in the time of the most powerful emperor Sultan Abdul Hamid I, the Year of the Hijra 1202 and of the Savior 1788, in Nikopol in Bulgaria. And it was finished in the days of the most powerful emperor Sultan Selim III in the year 1794 and 1208 in the month of Shawwal). For this study, I have used the most recent critical 
this purports to be a chronicle of the sultans and viziers who built the Ottoman Empire, in fact it proves to be an autobiographical journal, at least in its second part. As a model, he had the history written by Dimitrie Cantemir, Historia incrementorum atque decrementorum Aulae Othomanicae (1716), which he used and quoted. ${ }^{5}$

The scholarship on South-Eastern Europe and the Ottoman Empire as seen through the prism of travel narratives is abundant; while other studies have investigated the journeys of Ottoman subjects in the direction of "Europe."6 The journal of Ianache Văcărescu is all the more important in that so far it seems to be the only one of its kind for the Romanian Principalities. I would like to approach the text through the intermediary of the author and to analyze his interaction with the "others," "Frenchmen," "Germans," or "Europeans" as he calls them. This investigation is particularly important given Văcărescu's description of his encounters as a self-described "Turk" with other "Europeans." How does he see "Europe" and what does he retain from his travels and interactions? In many respects, his account of a diplomatic mission to Vienna parallels that of Ottoman ambassadors' experiences in the imperial capital, thus providing an important addition to the topic of such encounters. ${ }^{7}$ Other aspects of the mission refine our knowledge regarding the role of Ottoman Christian subjects and the way they interacted with the Sublime Porte. ${ }^{8}$ Therefore, the aim of the present study is to examine how Văcărescu employed the knowledge

edition of the works of Ianache Văcărescu. See Ianache Văcărescu, Istoria Othomanicească (Ottoman History), ed. Gabriel Ştrempel (Bucharest, 2001).

5 Dimitrie Cantemir's work was first printed in English translation as History of the Growth and Decay of the Othman Empire [...] by Demetrius Cantemir, late Prince of Moldavia (London, 1734), then in French, Histoire de l'Empire Othoman où se voyent les causes de son Aggrandissement et de sa Decadence par S.A.A. Demetrius Cantemir, Prince de Moldavie (Paris, 1743) and German, Geschichte des osmanischen Reiches nach seinem Anwachsen und Abnehmen, beschrieben von Demetrie Kantemir (Hamburg, 1745). For Dimitrie Cantemir, see Ştefan Lemny, Les Cantemir: l'aventure européenne d'une famille princière auXVIII ${ }^{e}$ siècle (Paris, 2009).

6 Under Eastern Eyes: A Comparative Introduction to East European Travel Writing on Europe, eds. Wendy Bracewell and Alex Drace-Francis (Budapest, 2008). Fatma Müge Göçek, East Encounters West: France and the Ottoman Empire in the Eighteenth Century (New York, 1987); Robert Dankoff, An Ottoman Mentality: The World of Evliya Çelebi (Leiden, 2006); Frédérick Hitzel, Prisonnier des infidèles: Un soldat ottoman dans l'Empire des Habsbourg, (Arles, 1998); and Hanna Dyâb, D'Alep à Paris: Les pérégrinations d'un jeune Syrien au temps de Louis XIV, trans. Paule Fahmé, Bernard Heyberger, and Jérôme Lentin (Arles, 2015).

7 Carter Vaughn Findley, “Ebu Bekir Ratib's Vienna Embassy Narrative: Discovering Austria or Propagandizing for Reform in Istanbul?," Wiener Zeitschrift für die Kunde des Morgenlandes 85 (1995): 41-80; and Virginia Aksan, An Ottoman Statesman in War and Peace: Ahmed Resmi Efendi, 1700-1783 (Leiden, 1995).

8 Virginia H. Aksan and Veysel Șimșek, "Introduction: Living in the Ottoman House," Journal of Ottoman Studies 44 (2014): 1-8. 
and manners acquired throughout his travels in both Ottoman and Habsburg empires to fashion his social status and to establish ties necessary for career advancement.

\section{Life and Family Background}

Ianache Văcărescu (1740-1797) came from an old Wallachian boyar family, whose existence is recorded already in the sixteenth century. ${ }^{9}$ His father, Ştefan Văcărescu, held an important office in the princely council, that of grand vornic. ${ }^{10}$ At the same time, he was a man with an interest in literary pursuits, which contributed very much to the education of his son. However, education did not have much importance for political advancement: boyars had access to important offices in the princely council according to their rank and the clientele networks to which they belonged. To change this it took the intervention of the Phanariot Prince Constantinos Mavrocordatos, who ordered that no boyar's son could hold office unless he went to school and learned Greek. ${ }^{11}$ Ianache Văcărescu, who was a child at the time, began his education stimulated by the "Enlightenment" ideas of this Phanariot prince. About the education of this important figure, much has been written and countless hypotheses have been put forward. ${ }^{12}$ We shall not go into detail here but merely recall an episode that was to contribute to his later writings. In 1763, his father, Grand Vornic Ştefan Văcărescu, was poisoned by the Phanariot Prince Constantinos Cehan Racovitza while at his country house in Valea Orlei, Prahova county. ${ }^{13}$ Ştefan's son, Ianache Văcărescu, took refuge in Constantinople, seeking help lest he suffer the same fate. Through his marriage to Elena Rizo, Ianache had an important connection in the Ottoman Empire in the person of his fatherin-law Iacovaki Rizo, an office-holder and a diplomatic representative of the

9 In the course of the eighteenth century, members of the Văcărescu family sought to construct a prestigious genealogy for themselves that would tie them to Wallachia's founding dynasty, see Biblioteca Academiei Române (hereafter BAR), Fond Manuscrise MS 305, f. $3 v$.

10 Cornel Cârstoiu, Ianache Văcărescu: Viaţa şi opera (Ianache Văcărescu: Life and Work) (Bucharest, 1974), 36-38. The post of Grand Vornic was equivalent to a minister of justice.

11 See the anaphora of May 9, 1746: V.A. Urechia, Istoria Şcoalelor (The History of Schools), vol. 1 (Bucharest, 1892), 14.

12 Cârstoiu, Văcărescu, 52-56; Văcărescu, Istoria Othomanicească, xix-xxii. His career in the Ottoman service shows parallels with those of other high-ranking Christian and Ottoman officials of this period. See, for instance, Fatih Yeşil, "How to Be(come) an Ottoman at the End of the Eighteenth Century," Journal of Ottoman Studies 44 (2014):123-139; and Philliou, Biography of an Empire.

13 Alexandru Odobescu, Opere: Collected Works, vol. 2 (Bucharest, 1967), 53. 
ruler at the Porte (kapıkâhaya) with important contacts in the world of the Phanar. ${ }^{14}$ According to Ianache's own account, ${ }^{15}$ his stay in Constantinople was a profitable one; for more than a year he studied Turkish in the company of the secretary of the Imperial divan, Halil Hamid, who was to become Vizier in 1783 . The family archive, with its maps, books, treatises, grammars, and dictionaries testifies to Ianache's linguistic ability. He had a good knowledge of Greek, Turkish, French, Italian, and German, and made use of these skills in his political and diplomatic ascent to become a key figure in negotiations between the Phanariot princes, the Sublime Porte, the Russian Empire, and the Habsburg Empire. ${ }^{16}$

Ianache was, in fact, a link in a vast network of family and patronage relations made up of diplomats, dragomans, viziers, ayans, and diplomatic agents, which linked Istanbul, via Bucharest, with Vienna, and, in fact, with Europe. He was married three times, his fathers-in-law being dragomans and princes, holders of important offices at the court of the Sultan and the Patriarchate of Constantinople. ${ }^{17}$ He himself held high offices in the Wallachian state (grand spătar, ${ }^{18}$ grand treasurer, grand $\left.b a n^{19}\right)$, being all the time a leading member of the princely council (divan).

\section{Circulation of Objects, Circulation of People: Ottoman Coffee vs. European Coffee}

Around 1780, the boyar elite followed Ottoman fashion and etiquette: costume, behavior, cuisine, and sociability were all strongly influenced by Constantinople. The predominance of the Ottoman model is confirmed by

14 Frequently mentioned in diplomatic correspondence, Iacovaki Rizo was a very influential figure and member of a network that covered the European embassies in Constantinople,

Eudoxiu de Hurmuzaki, Documente privitoare la istoria românilor (Documents Regarding the History of Romanians) vol. 7 (hereafter Hurmuzaki) (Bucharest, 1897), 20, 134, 172, 269, 280, 291; and ead. vol. 9: part 2, 113.

15 Văcărescu, Istoria Othomanicească, 219.

16 In addition to this history of the Ottoman Empire, Ianache Văcărescu wrote the first grammar of Romanian, printed simultaneously in Râmnic and in Vienna (1787), compiled bilingual German-Romanian and Turkish-Romanian dictionaries, and wrote poetry.

17 Following the death of his first wife (Elena Rizo) in September 1780, Ianache was married in December 1781 to Elena Caradja, the daughter of Iordaki Caradja, tercüman at the court of Constantinople. He was unlucky this time too, as Elena died seven months later, and he was married a third time in September 1782 to Ecaterina Caradja, the daughter of Prince Nicolae Caradja. See Cârstoiu, Văcărescu, 72.

18 Literally sword-bearer, the high office-holder in charge of the armed forces and the police.

19 Governor of Oltenia, the highest office in the princely council. 


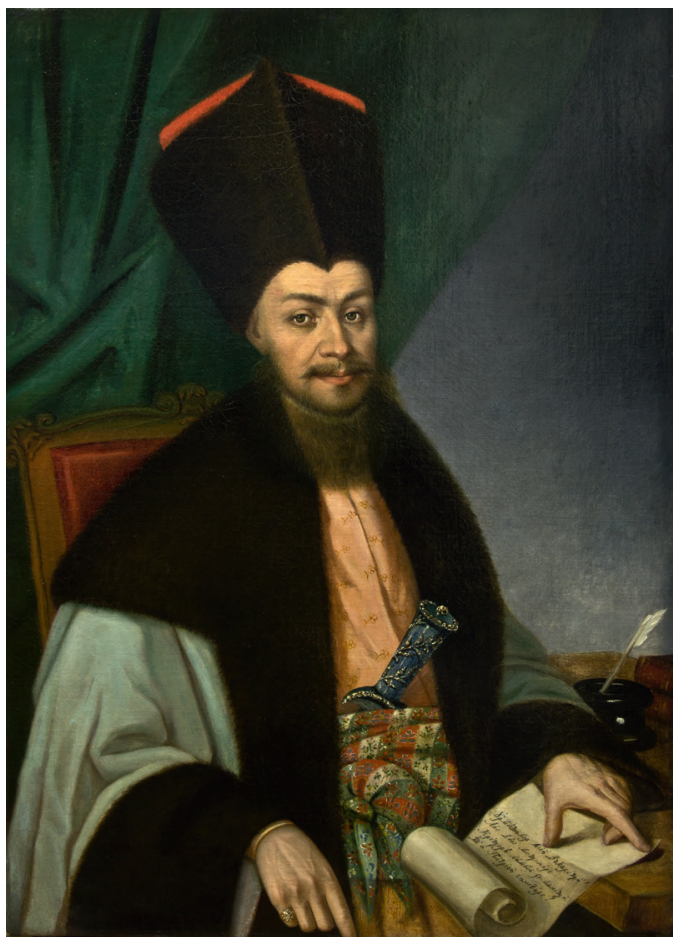

FIGURE 1

Anton Chladek, Ianache Văcărescu, oil on canvas

COURTESY (C) NATIONAL MUSEUM OF ART, BUCHAREST.

travelers who arrived in the Romanian capitals. Fashion, imposed by the political regime, proved to be an indispensable form of subjection in the context of Phanariot rule. At the same time, through its opulence and luxury, this Ottoman costume served a process of self-fashioning. ${ }^{20}$ Ianache Văcărescu helps us to understand this process of construction of the self, which may be reconstituted both through the intermediary of his writings of an autobiographical character and, visually, with the help of his portraits. ${ }^{21}$

Our information about the daily life of holders of high office at this time, about the organization of their mansions or their interior decoration and

20 For the Romanian boyar class and the construction of identity through luxury and fashion, see Constanţa Vintilă-Ghiţulescu, "Shawls and Sable Furs: How to be a Boyar under the Phanariot Regime (1710-1821)," in European History Yearbook 20 (2019): 137-158. In recent research, the term "Ottomanization" has been proposed to explain the rapid adoption of Ottoman costume by the Christian population on the borders of the Ottoman Empire. See Michał Wasiucionek, "Conceptualizing Moldavian Ottomanness: Elite Culture and Ottomanization of the Seventeenth-Century Moldavian Boyars," Medieval and Early Modern Studies for Central and Eastern Europe 8 (2016): 39-78.

21 See his portraits by Anton Chladek. 
furniture, is relatively scanty, especially for the eighteenth century. Because of the wealth of details regarding material culture and luxury consumption that it offers, the Văcărescu family archive and library have become an essential source for a reconstruction of the way of life of a high office-holder of the Phanariot period.

Ianache Văcărescu's mansion, situated in the vicinity of the princely court, was organized according to the Ottoman model. ${ }^{22}$ His journeys, whether on diplomatic missions or simply seeking refuge in time of war, took him to Braşov, Vidin, Silistra, Nikopol, Rhodes, Constantinople, and Vienna. People and objects would influence his lifestyle, his behavior, and would mold his thinking and his manners. ${ }^{23}$

The Russo-Turkish War (1769-1774), in which he was one of the leading figures, took him on a mission and then into exile in Braşov. Here he met for the first time the young sovereign Joseph II. ${ }^{24}$ The meeting brought together two different social and political models, and the behavior of Văcărescu, the high office-holder, now in exile, was adapted and modeled to take account of the new context. Here is what he writes:

In this year, 1773, May, the Emperor of the Romans Joseph II, wishing to go to Galicia and Lodomeria, to the lands that he had then obtained, crossing the borders of Transylvania came to Braşov, where he stayed for three days and did us Romanian boyars who were guests there great honor, for as soon as he arrived at the mansion prepared for him, he at once sent the doctor of his Imperial Majesty to us, where we were all gathered in my

22 Orthodox bishop Grigore of Argeș provided a description of the mansion, calling it worthy of a great pasha, see Odobescu, Opere, vol. 2: 75-77. For the manner in which the house of a Turkish pasha was organized, see the interesting analysis made by Hedda Reindl-Kiel, "The Must-Haves of a Grand Vizier: Merzifonlu Kara Mustafa Pasha's Luxury Assets," in Sonderdruck aus: Wiener Zeitschrift für die Kunde des Morgenlandes, ed. Michael Jursa, Markus Köhbach, Rüdiger Lohlker, and Stephan Procházka (Wien, 2016), 179-221.

23 For example, Văcărescu's mansion in Băneasa, built around 1784-1785 following the boyar's return from Brașov, was inspired by "German" models, as stipulated by contracts he had signed with mason Johann Ratner and carpenter Theodor Janos, see Nicolae Iorga, Studii și documente cu privire la istoria românilor (Studies and Documents Regarding the History of Romanians) vol. 3 (Bucharest, 1901), 79-8o.

24 The Habsburg authorities in Vienna were aware of the Wallachian and Moldavian boyars who had taken refuge in Brașov. The boyars' correspondence with Chancellor Kaunitz shows that they requested protection, asylum, passports, and other favors. See Österreichisches Staatsarchiv, Haus-, Hof-, und Staatsarchiv, Staatenabteilung (HHStA) Moldau-Walachei I/26/Vaccaresculi (1772-1773) and Brancovan (1767-1777). 
lodgings [...], and invited us to come the next day at ten o'clock for him to give us an audience. ${ }^{25}$

The audience took place as announced, providing Ianache with a good occasion to showcase his abilities by providing "dragoman service to the boyars in the Italian language." Highly proficient in the language of diplomacy, Ianache Văcărescu pushed himself into proximity of the Emperor, who invited him to accompany him to the ball held in honor of the Wallachian boyars taking refuge in Braşov: "Signor Văcărescu," said the Emperor, "I invite you and put you to the trouble of doing me this evening the service of an interpreter." Ianache's answer was one befitting an experienced diplomat: "Bowing, I replied to him that this was the happiest night I had encountered in the world since I was born." He continued: "and so, taking him by the left arm, I was in this service and honor until an hour after midnight, allowing no boyar or lady to go without asking some question." 26

His three days spent in the company of Emperor Joseph II, together with his several years of exile in Braşov (he would leave the city in September 1774) contributed to the remodeling of Ianache's tastes and manners. On July 16, 1773, the boyar compiled a list of purchases that reflects the influence of objects and the new lifestyle on his conduct. He asked for a series of items of tableware to be procured direct from Vienna, among them: soup bowls, metal trays, dishes, spoons, forks, knives, jugs, cups, sugar bowls, trays, plates, salt cellars, candlesticks, and candelabra, all of silver or porcelain. What gives this list its significance is not the quantities involved but the eye of the boyar, who has looked at length at the object, has been impressed, and now wishes to enroll in a trend, convinced of the validity and grandeur of the model to be followed. Nothing is left to chance, and "Europe" becomes the keyword. The metal trays must be large, slightly oval, with handles "as is usual there in Europe." ${ }^{27}$ The boyar had

25 Văcărescu, Istoria Othomanicească, 116.

26 Ibid., 117. Emperor Joseph II noted (June 6, 1773) this social encounter with the Romanian boyars who had taken refuge in Braşov: "Hernach giengen wir in die Gessellschaft zum General Eichholz so alle Boerinnen und Griechinnen eingeladen hatte. Er scheinet ein alter wohlgedienter Mann zu seÿn, der ziemlich gut informiret ist, von hiesigen Gegenden. Es waren etlich und 20 . Griechinnen, alle magnifique angelegt, und welche mitsammen theils spieleten, theils so sitzeten, aber keine einzige konnte eine Sprache als griechischen und wallachisch. Ich redete mit den Herrn eine." See Călătoria împăratului Iosif al II-lea in Transilvania la 1773 (Journey of Emperor Joseph II to Transylvania in 1773), ed. Ileana Bozac and Teodor Pavel (Cluj, 2017), 629.

27 See the list in Mihai Carataşu, Documentele Văcăreştilor (Documents of the Văcărescu Family) (Bucharest, 1975), 59-61. 
not yet been as far as "there in Europe," but only to Braşov, a city belonging to the Habsburg Empire at the time, where he had often been invited to dine in the houses of local notables. The objects induce another manner of serving dinner, another vision on sociability over coffee, another ceremony of aesthetic exhibition of cuisine. Thus, we find very detailed requirements that imply certain gestures, bodily self-control, certain manners, and a different type of behavior. For example, he asked that "the forks be with three prongs, that is, in the form of those of the English type." The salt is no longer poured on the table but in a silver salt cellar; the mustard gets a jug, and also a little spoon; the oil also has its jug, because "that is how the Europeans do it." It would appear that, up till this date, the fork was absent from the tables of boyars in Wallachia and Moldavia. ${ }^{28}$ Ottoman influence, which became permanent and dominant with the establishment of the Phanariot regime, led to the loss of this object of civility to which Norbert Elias attributes a special significance in the propagation of good manners. ${ }^{29}$

The same requirements are found with regard to the ritual of coffeedrinking. The boyar Ianache Văcărescu asked for "European cups and in no circumstances Turkish coffee-cups." They should be accompanied by "a 'proportion' jug too for milk" and a sugar bowl from which the sugar will no longer be taken with the fingers but "as the Europeans do with tongs, who take the sugar and put it in the cup."30

To understand these changes, let us consider the way in which coffee was served in a boyar salon, as experienced by the German doctor Andreas Wolf, around 1784:

The master of the house claps his hands (this is a usual signal which replaces the bell used in our country), and, at once, the reception room is filled with servants. The housemaid, usually a Gypsy, brings on a silver

28 An analysis of dowry agreements and inventories for the period 1700-1800, finds forks present in the dowry agreements of the children of Prince Constantine Brâncoveanu (1688-1714), included in the item "12 pairs of knives, with their forks and spoons." It cannot be said with certainty that forks were in regular use. The princely family could be an exception. After this date, however, the expression is simply: "12 pairs of silver knives and spoons." under the heading "Silverware." The fork reappears in the context of the Russian military occupations in the nineteenth century. See Constanţa Vintilă-Ghiţulescu, Patimă şi desfătare. Despre lucrurile mărunte ale vieţii cotidiene în societatea românească: 17501860 (Passion and Pleasure: On Minor Things of Everyday Life in Romanian Society, 17501860) (Bucharest, 2015), 140-147.

29 Norbert Elias, La civilisation des mours (Paris, 1973), 180.

3o Carataşu, Documentele, 59-61. 
tray a glass of fresh water, together with a pretty bowl, containing the so-called dulceaţă. This she hands over to the lady, who then serves each guest by hand. Because this is the first sign of the honors, regardless of the day or season, to refuse would signify a lack of good manners. The guest thus takes a good spoonful, and then drinks as much water after it as he desires. Meanwhile the coffee-bearer appears with his tray, on which sit the jug of coffee and the cups with their supports. The coffee is served unfiltered, and usually (prepared) without sugar, as I have seen among the Turks. The mistress of the house holds out in her hand a cup of coffee to each guest; in that moment the pipe-server approaches and offers to each in turn a pipe lit right then. ${ }^{31}$

Coffee was an important ingredient, part of a ritual of socialization practiced both at the princely court and at the courts of the boyars. However, coffee was not offered alone, but, copying the Ottoman model, it was associated with dulceaţă (fruit conserve), sherbet, and the indispensable pipe. ${ }^{32}$ Ianache Văcărescu was moving towards the Viennese model, which transformed only the coffee, by adding milk and sugar, but not the ritual of socialization. ${ }^{33}$ For this "Viennese model," he needed different objects: "European cups," tongs, sugar bowls, and milk jugs, which he ordered with insistence from his Viennese supplier. ${ }^{34}$ All this silverware was to be "suitable in weight, neither too heavy nor too light, but as is customary these days among the nobility in Europe." And it should fit inside a trunk "lined with fabric inside and [covered] with leather and bound with thick iron wire."35

All of these objects were commissioned to perform the practices of sociability specific to Brașov. Prince Nicolae Brâncoveanu, another refugee boyar in Brașov, also stated that social status had to be upheld everywhere and in all circumstances. ${ }^{36}$ While this imperative was complicated by their temporary resi-

31 Andreas Wolf was a Transylvanian Saxon, a doctor at the princely court of Moldavia. He came to Moldavia in 1780 and stayed at the court until 1783. In 1784 he was in Wallachia, returning to Moldavia in 1788-179o and 1796-1797. See Andreas Wolf, Beiträge zur einer statistich-historischen Beschreibung des Fürstenthums Moldau (Sibiu, 18०5), 218-219.

32 For the coffee ritual seeVintilă-Ghiţulescu, Patimă, 149-157.

33 David Do Paço shows how coffee became part of a ritual of diplomatic meetings between Turks and Austrians in "Comment le café devient viennois. Métissage et cosmopolitisme urbain dans l'Europe du XVIII e siècle," in Hypothèses 2011: Travaux de l'École doctorale d'histoire (Paris, 2012), 351.

34 Carataşu, Documentele, 59-61.

35 Ibid.

36 HHStA, Moldau-Walachei I/26/ Brancovan, f. 13, 15 January 1772. 
dence in a foreign country, the consciousness of rank overrode any difficulties. In order to maintain his social prestige, on March 6, 1773 Ianache Văcărescu requested a loan of 8,00o florins from Chancellor Kaunitz, at the same time stressing his "humiliation" at being forced to do so. ${ }^{37}$

In the end, Braşov proved to be the stage on which the actors of the two great empires met, interacting through dialogue and socialization, exchanging ideas and above all cultural values. Significantly, Ianache provided the Emperor with information and with his vision of the Ottoman Empire and of the political situation in its peripheral regions. As a translator and interpreter, he mediated the differences between the two cultural environments. ${ }^{38}$

\section{In Șalvar and Işlic to Vienna}

As was mentioned at the beginning of this study, the flight of the sons of the Wallachian prince Alexandros Yspilantis to "the lands of Europe" triggered a diplomatic scandal. ${ }^{39}$ As Ottoman subjects, Constantinos and Dimitrios could cross the border only if the Sultan gave his accord, which was almost unthinkable given that their father held the position of ruling prince of Wallachia.

Alexandros Ypsilantis went to considerable effort in the hope of bringing his sons home before the news reached Istanbul. An intense diplomatic correspondence took place with the court of Vienna, ${ }^{40}$ with a view to having the wayward sons extradited, while the young men's teacher, Ignatius Stephan Raicevich, was sent on their trail. ${ }^{41}$ As for the runaways themselves, Constantinos and Dimitrios Ypsilantis, aged nineteen and seventeen respectively, wrote to Friedrich von Preiss, chief of the imperial army in Transylvania, and to Emperor Joseph II that their flight had been hastened by "the bad

37 The chancellor dismissed the request, arguing that "I'Imperatrice-Reine" had to give priority to her subjects, whose interests had to take precedence over those of foreigners in the distribution of benefices and money (April 19, 1773, Vienna). HHStA Moldau-Walachei I/26/Vaccaresculi, f. 39-40; See also Andrei Pippidi, Documente privind locul românilor în Sud-estul Europei (Bucharest, 2018), 266-267.

38 It is unclear whether Văcărescu was the recipient of a letter that arrived from Vienna on November 15, 1777. Written in German, it provides a detailed description of social events in the Habsburg capital, see BAR, fond Documente Istorice, CCCI/49.

39 The event attracted such popular interest that the story was quickly versified and circulated in the alleys of market towns in the form of a poem. See Cronicişi povestiri româneşti versificate (sec. XVII-XVIII), ed. Dan Simonescu (Bucharest, 1967), 221-224.

40 HHStA, Moldau-Walachei I/26, Ipsilanti (1775-1793), 9-11, ff. 30-40, Türkei, II/77, ff. 55-57.

41 Hurmuzaki, vol. 7: 331 . 
treatment they suffered from their parents," that their lives and those of all Christians were always insecure in Turkey, that they wanted to learn in Vienna, the most enlightened place in Europe, and that they put themselves at the service of the Emperor, for whom they were prepared to lay down their lives. ${ }^{42}$ In an age in which travel was perceived as a means of education, especially in the case of young noblemen, the attitude of the Austrian authorities was somewhat encouraging. Neither General Preiss nor Chancellor Kaunitz nor even Emperor Joseph II seemed in any hurry to give orders for the young men to be sent back to Wallachia. ${ }^{43}$

Afraid that he might lose his head, Alexandros Ypsilantis sent a new mission to track his sons, this time a much more impressive one, consisting of Metropolitan Grigorie of Wallachia, Bishop Filaret of Râmnic, grand ban Dumitrache Ghica, and grand spătar Ianache Văcărescu, almost half of the princely council, in the hope that they could "urge the enlightened young gentlemen to come back." ${ }^{44}$ For the boyars of Wallachia, the Ypsilantis boys' exploit could only be interpreted as "a criminal flight" that "compromised their father forever" and destroyed "the tranquility and safety of our country." So writes Ianache Văcărescu in his letter to General Preiss, asking the latter to stop the young men in Transylvania. ${ }^{45}$ We are thus faced with two different systems of thought: Joseph II and his diplomatic representatives speak of "individual will" and personal liberty while Ianache Văcărescu speaks of "submission and fidelity towards the Porte" and total obedience to their father.

The court of Vienna became the grand stage on which the Wallachian officeholder played the role of wealthy boyar, polyglot diplomat, and elegant gentleman. ${ }^{46} \mathrm{He}$ attracted the gaze of those around because he was a "Turk,"47 or was defined as such by himself, but above all because he was a "foreigner" of startling opulence. Prince Kaunitz introduced him into the Viennese atmosphere:

He took me by the hand and went out into the assembly room, where were gathered all the ambassadors of the courts and the most brilliant

\footnotetext{
42 Hurmuzaki, vol. 7: January 8, 1782, 339-340.

43 Hurmuzaki, vol. 7: February 8, 1782.

44 Văcărescu, Istoria Othomanicească, 127. On "Ottoman Vienna" at the end of eighteenth century, see David Do Paço, L'Orient à Vienne au dix-huitième siècle (Oxford, 2015).

45 Hurmuzaki, vol. 7: February 13, 1782, Cronstat, 345.

46 Ianache arrived in Vienna on January 25, 1782.

47 On the use of the denomination "Turk" see Palmira Brummett, "You Say 'Classical', I Say 'Imperial', Let's Call the Whole Thing Off: Empire, Individual, and Encounter in Travel Narratives of the Ottoman Empire," Journal of Ottoman Studies 44 (2014): 21-44.
} 
ladies in Vienna. I made the acquaintance of them all and they greeted me with affection and with honor ... Prince Kaunitz found the occasion to praise the sable furs in which I was dressed (for the Europeans habitually speak casually of these things, and to people they have met for the first time). And at that assembly the ladies undid my sash, to see my shawl. ${ }^{48}$

Everything gave off an air of extravagance: Lahore shawl, sable furs, diamond ring, silk anter ${ }^{49}$ and brocaded fermene, ${ }^{50}$ khanjar inlaid with precious stones, and sahtiyan leather slippers. The Wallachian official on a diplomatic mission was the living image of what a "Turk" ought to be. He quickly became the star attraction of the salons, enjoying the company of Chancellor Kaunitz, Grand Duke Paul of Russia, French ambassador Louis August Le Tonnelier de Breteuil, ${ }^{51}$ Vice-chancellor Philipp von Cobenzl, the Spanish ambassador, and Archduke Maximilian. The boyar entered into the logic of Viennese protocol, paying visits of courtesy and greeting: "I went to all the ambassadors to greet them with notes and when I returned to my lodgings to dine all the ambassadors came to me to greet me with notes." 52

Expensive furs were very important for the maintenance of prestige. Their very high price turned them into luxury objects, often forbidden by means of sumptuary laws, and at the same time important gifts in diplomatic relations. ${ }^{53}$ Prince Kaunitz insisted on knowing the price of the sable furs that decorated Ianache's cüppe, ${ }^{54}$ and then asked him to offer advice on the pricing of some gifts: "He said to me: 'Let me show you a sable fur that the Crown Prince of

48 Văcărescu, Istoria Othomanicească, 129-130.

49 A long robe.

$5^{\circ} \quad$ A short embroidered jacket, worn over the anteri.

51 Văcărescu emphasized the attention and respect he received from French ambassador Berteuil, who tried to ingratiate himself with the "Sublime Devlet." Upon grasping the underlying reason for this "abundance of ceremonies" on Berteuil's part, Văcărescu responded to him as to "a Turk," causing the diplomat "much satisfaction," Văcărescu, Istoria Othomanicească, 131 .

52 Ibid., 131.

53 Donald Quataert, "Clothing Laws, the State and Society in the Ottoman Empire, 17201829," International Journal of Middle Eastern Studies 29, no. 3 (1997): 403-425; Hedda Reindl-Kiel, "Luxury, Power Strategies and the Question of Corruption: Gifting in the Ottoman Elite (16th-18th Centuries)," in Şehrâyîn. Die Welt der Osmanen, die Osmanen in der Welt, Wahrnehmungen, Begegnungen und Abgrenzungen: Festschrift Hans Georg Majer, ed. Yavuz Köse (Wiesbaden, 2012), 107-120.

A long felt coat, often lined and trimmed with fur. 
Russia gave me and I pray you tell me its price.' He brought the fur and put it on the billiard table." The situation seems difficult given that the Wallachian official wore furs much more expensive and more beautiful than those received by his Viennese host, so he saved himself by means of the rhetoric of diplomacy: "I answered him that neither by sunlight nor at night can sable furs be priced properly. This fur, however, taking into account the place from which it was given and the place to which it was given, is priceless. And I, even if I had seen it by day, do not have the skill to price it.".55

He again becomes a "Turk" when he enters the palace of Emperor Joseph II, which he described in lavish details, impressed as he was by "the pavilion with marble pillars supported on the backs of lions," by "the curtains that hang from the baldachin worked with gold," by "the folded draperies with metallic thread," by the pearls decorating them, by the guards, the swords, the multitude of rooms, of cabinets, etc. ${ }^{56}$ It is a meeting of two different worlds: Joseph II, the adept of ceremony made as simple as possible, ${ }^{57}$ and Ianache Văcărescu, the adept of Ottoman diplomatic protocol:

As I went in through the door, I saw the Kaiser in the middle of the room, on his feet and without a hat, and taking two steps forward I knelt down in the Turkish manner, and after putting my head on the ground, when I wanted to raise it, I found myself with the Kaiser's hand on my head; he said to me that he did not require this ceremony and I should rise, and when I wanted to kiss his hand, he pulled it away. 58

Ottoman protocol, as staged by Ianache Văcărescu, suddenly became insignificant and rather embarrassing when Joseph II withdrew the hand that was about to be kissed. 59

55 Văcărescu, Istoria Othomanicească, 130. A similar scene can be found in the account of Ebu Bekir Ratıb, Ottoman ambassador to Vienna in 1792. This time, the scene focused on Prince Kaunitz and his horse-riding skills, see Findley, "Ebu Bekir Ratib's Vienna Embassy," 65. For Kaunitz's behavior see Franz A. Szabo, Kaunitz and Enlightened Absolutism 17531780 (Cambridge, 1994), 20-35.

$5^{6}$ Văcărescu, Istoria Othomanicească, 133.

57 Barbara Stollberg-Rilinger, Les vieux habits de l'empereur. Une histoire culturelle des institutions du Saint-Empire à l'époque moderne (Paris, 2008), 312. For Joseph II and court ceremonial, see Derek Beales, Joseph II: Against the World, 1780-179o (Cambridge, 2013).

58 Văcărescu, Istoria Othomanicească, 133 .

59 In the meantime, events had taken a new turn in Wallachia. Alexandros Ypsilantis had given up the throne and had named Ianache Văcărescu as kaymakam, Văcărescu, Istoria Othomanicească, 135 . 
In Wallachia, the boyars followed Ottoman protocol, kissing the ruling prince's hand and/or the hems of his robes as a form of respect and of recognition of hierarchies. ${ }^{60}$ Meanwhile Joseph II had forbidden kneeling by an imperial decree (1787), considering that it was "not a fitting form of behavior from one human being to another and should be reserved for God alone."61 Kneeling and kissing of hands were part of a cultural code put into practice in the Ottoman Empire and respected strictly on its peripheries, at the borders between rival empires. ${ }^{62}$

The audience lasted more than two hours. Joseph II argued the case for individual free will, imperial hospitality, and political asylum for young men who want to study and the freedom to travel, stressing that the young princes may be advised to return home but under no circumstances forced to do so. ${ }^{63}$ The Wallachian office-holder, an Ottoman subject, asks for no more and no less than their expulsion by force, emphasizing that his whole career depends on the success of this diplomatic mission:

Besides the effort that to my great honor and praise I have made to come, I will lose what little reputation and standing (ypolipsis) I have in all the principality of Wallachia, where to the sorrow I feel on account of these happenings is added that of being incapable of carrying [my mission] to a conclusion and unable to obtain justice even from the very justice itself that you are, your Imperial Majesty. ${ }^{64}$

6o In Wallachia, "the custom of kissing the prince's hand as a sign of subjection" would be abolished only on July 21, 1834, by a princely decree sent to all departments, Arhivele Naţionale Istorice Centrale (AN), Fond Achiziţii Noi, mmmxxxıx/1; AN/Vâlcea, Fond Prefectura Judeţului Vâlcea, 35/1834; AN/Buzău, Fond Subocârmuirea Plaiului despre Buzău, 53/1834.

61 T.C.W. Blanning, Joseph II (London, 2013), 64; On diplomatic ritual, see also: Christine Vogel, "The Caftan and the Sword: Dress and Diplomacy in Ottoman-French Relations Around 1700," in Fashioning the Self in Transcultural Settings: The Uses and Significance of Dress in Self-Narratives, eds. Claudia Ulbrich and Richard Wittmann (Würzburg, 2015), $25-45$.

62 For the Ottoman protocol of hand-kissing, see Palmira Brummett, "A Kiss is Just a Kiss: Rituals of Submission along the East-West Divide," in Cultural Encounters between East and West, 1453-1699, ed. Matthew Birchwood and Matthew Dimmock (Cambridge, 2005), 107-131.

63 HHStA, Türkei, II $/ 77$, f. 11, 6o.

64 Văcărescu, Istoria Othomanicească, 136. 
Impressed by the rhetoric of the Wallachian boyar, but also as a consequence of the information with which he has been provided ${ }^{65}$ - he is known to have had a "mania for gathering detailed information about all manner of social phenomena"66_Emperor Joseph II promised that he would not receive the Ypsilantis princes into his service: "I promise you upon my imperial word that neither in my lands nor in my service will I keep them, and I will certainly return them to Turkey, only that I must first bring them here, to ensure that they have a pleasant stay, without worries." 67 In other words, the good manners specific to diplomatic ceremonial must be respected to the end, and the right to hospitality remains a principle that cannot be stepped over.

\section{Being a Boyar: Luxury, Civility, and Prestige}

Travelling across empires, entering into contact with different forms of civilization, dealing skillfully with languages and people, Ianache Văcărescu is a key figure for the understanding of peripheries. Wallachia and Moldavia were "contact zones," to borrow the term used by Mary Louise Pratt, where, for more than a century, three great empires, Ottoman, Habsburg, and Russian, had met. ${ }^{68}$ The meetings between the three cultures are reflected in memorialistic writings, which try to define identity and alterity in relation to the other. ${ }^{69}$ The local elite is the bearer of this "cultural mix." Although common features often unite the narrators and their characters, these seem to get lost when the test of civility is set out as an inexorable criterion. In many cases, the writers of travel narratives do not understand the way of being of these boyars, even if it fascinates or intrigues them, and thus they categorize them as "barbarian." Even those who have spent many years among them, occupying official positions, are repelled and criticize certain customs or behaviors, which are always entered in the balance of alterity. Consuls, ambassadors, diplomats, missionaries, or simple travelers are the guests of the courts and

65 IanacheVăcărescu writes: "He asked me many questions, about Tsarigrad(Constantinople), about Wallachia, about customs and other things," Ibid., 136.

66 Pieter M. Judson, The Habsburg Empire: A New History (Cambridge, 2016), 55.

67 Văcărescu, Istoria Othomanicească, 136.

68 Mary Louise Pratt, Imperial Eyes: Travel Writing and Transculturation (New York, 1992), 4.

69 For this topic, see Larry Wolff, Inventing Eastern Europe: The Map of Civilization on the Mind of the Enlightenment (Stanford, 1994); and Maria Todorova, Imagining the Balkans (Oxford, 1997). 
mansions of the boyars, which they then describe in their eager quest for turqueries. ${ }^{70}$ Good manners as a form of social distinction and self-fashioning were very much in vogue in Central and Northern Europe. For the Wallachian boyars, the model of good behavior was inspired by the manners and conduct displayed by the Phanariot princes at the princely court. The manners and conduct of the Phanariot princes were adapted according to the context and the guests: "Greek," "Turkish," and "Ottoman" in the company of Ottoman envoys and Wallachian office-holders, "French" in the company of "Western travelers."

In his book devoted to the Ottoman Empire, Ianache Văcărescu often used the term ypolipsis (and never politíe), to describe the behavior of others and to speak about himself. His readings were diverse and in various languages, ${ }^{71}$ but when it came to good manners, and above all conduct, although he had read Il giovane istruito, ${ }^{72}$ he preferred the Greek word ypolipsis (i $\pi \dot{\lambda} \lambda \eta \psi(\varsigma)$. The significance of the term ypolipsis was connected to the place one occupied in society, to the social classifications made by others, to the way one was seen by others, and to a certain status displayed and promoted. For Văcărescu, ypolipsis represented a public recognition of his learning and wisdom. The individual with ypolipsis is the one who shows himself, by his accumulation of knowledge and learning, to have wisdom. True learning is that which brings wisdom, and together they lead to respect, prestige, and fame. Prestige is recognized by measures capable of ensuring "the well-being of all." ${ }^{33}$ This ypolipsis may be quickly lost if the individual does not strive always to retain people's respect. This is what he is speaking of when he seeks the help of Emperor Joseph II to recover the sons of Prince Ypsilantis, and the term is clothed in the same sense when he uses it to characterize others. Consider what he says about Alexandros Mavrocordatos, the dragoman of the Porte, whom he describes as "a man of a subtle and lively spirit," with immortal ypolipsis, obtained by virtue of "noteworthy service to the Empire,"74 or Selim Pasha, kapıcibaşa of Nikopol,

70 See Alexandros Bevilacqua and Helen Pfeifer, "Turquerie: Culture in Motion, 1650-1750," Past and Present 221 (2013): 75-118.

71 Văcărescu frequently borrowed Greek, Italian, French, Turkish, or German terms to convey notions without equivalent in Romanian.

72 The reference is to the work of the Italian author Geminiano Gaetti, Il giovane istruito ne'dogmi catolici: nella verita della religione cristiana e sua morale (Venice, 1749). Serdar Anton Manuil composed a Greek translation, published in 1794 and dedicated to Spătar Ianache Văcărescu (Cârstoiu, Văcărescu, 227).

73 Văcărescu, Istoria Othomanicească, 94.

74 Ibid., 77-78. 
who is "learned and wise."75 Ianache Văcărescu presents himself as the foremost boyar of Wallachia, a man of great ypolipsis, worthy to be ruler of the principality. ${ }^{76}$ Those around him, "Greeks" or "Turks" like himself, describe him in the same terms. "You have heard of the wealthy Vakarescolo, the Croesus of Boyars," says Iordache Condilo admiringly, ${ }^{77}$ while Prince Alexandros Mourouzis, elevating Văcărescu to the office of grand ban, recognizes him as "the foremost noble boyar [...] capable and with good ypolipsis." Mourouzis held this opinion despite having every reason to hate the "worthy" and "faithful" boyar, given the rumors that Văcărescu was Princess Zoe Mourouzis's lover: the voyvode heard the populace singing daily under his window of their illicit and "fiery passion." ${ }^{\text {. }}$

The high office-holder Ianache Văcărescu gave particular attention to the body that was seen, to appearances, and to the education of the mind. At a certain point in his memoirs, he wonders which it is better to have, "a jar of good fortune or a drop of intelligence," and he answers: "A splash of intelligence I want, rather than good fortune."79 And so he would be all his life, educating his mind with diverse reading and writing and taking care of his body. Nevertheless, the education of the mind and the care of the body did not turn him into a "giovano istruito" such as the ambassadors, princes, and chancellors-in a word, the "Europeans"-considered themselves to be. Consider the following eye-witness account by the Swiss Franz Joseph Sulzer, one of the secretaries of the princely court in the time of Alexandros Ypsilantis and an Austrian agent in Wallachia, who knew the elite at the princely court at close quarters. Invited to a ball held there in 1778 , he describes the atmosphere as follows:

75 Ibid., 149

76 Ibid., 103. Alex Drace-Francis also points out this eagerness for underlining his social distinction when he signed his books as a dikaiophylax of the Great Eastern Church. See Alex Drace-Francis, The Making of Modern Romanian Culture. Literacy and the Development of National Identity (London, 2006), 63. Similarly high levels of self-esteem can be found among the Ottoman diplomats discussed by Denis Klein, "The Sultan's Envoys Speak: The Ego in 18th Century Ottoman Sefâretnâmes on Russia," in Many Ways of Speaking About Self: Middle Eastern Ego-Documents in Arabic, Persian and Turkish (14th-2oth Century), eds. Ralf Elger and Yavuz Köse (Wiesbaden, 2010), 89-103.

77 Iordache Condilo was the brother-in-law of the Phanariot prince Nicholas Mavrogenis (1786-179o) and a diplomatic agent. He appears as a character in the novel Anastasius by Thomas Hope (London, 1819), II: 293.

78 See the document of April 30, 1795, in Urechia, Istoria, vol. 5: 306-307.

79 Văcărescu, Istoria Othomanicească, 118. 
At the table of the Prince of Wallachia, the Grand Ban Dudescu wanted to honor the name day of the Prince, which was celebrated then, with an unusual toast. Perhaps he had drunk too much. He stood up as the foremost boyar in the land, according to custom, together with the Metropolitan, and the whole table stood up after them; he uttered his toast, tasted a little from the great toasting cup, and poured the rest of the cup in the face of the Grand Vornic Filipescu, so that the wine flowed over his beard and over his fur, down to the ground. ${ }^{80}$

For Sulzer, with his Jesuit education and experience of the discipline of an Austrian infantry regiment, the toast is nothing but "the playful fancy of a drunkard." 81 The unusual toast was, however, a local custom, which is also recorded elsewhere. For example in the collection Îndreptări moraliceşti tinerilor foarte folositoare (Very useful moral directions for the young), Dimitrie Tichindeal notes and condemns such behavior: "abandon the foolish and vulgar custom that some observe towards their friends and their beloved wife, that the wine that they cannot drink from the glass they pour on the clothes of those who cannot drink it. This is great foolishness and vulgarity." 82 At another ball, also at the princely court, Sulzer is scandalized by the sight of elegant ladies eating with their fingers from a common dish, eagerly devouring the food "without forks." 83 Nor does he have a better opinion about our Văcărescu: among the exiles in Braşov in 1774, Sulzer is witness to a truly revolting scene: "At the official ball of the commandant of Braşov, the grand vistier [i.e. Ianache Văcărescu] got so drunk that he threw up in the ballroom all that he had consumed." 84 Sulzer notes the excesses of this boyar class, whom he does not like much and among whom he did not manage to integrate himself, although he spent more than eleven years in Wallachia.

8o Franz Joseph Sulzer, Geschichte des transalpinischen Daciens, das ist der Walachey, Moldau und Bessarabiens. Im Zusammenhange mit der Geschichte des übrigen Daciens als ein Versuch einer allgemeinen dacischen Geschichte mit kritischer Freyheit entworfen, vol. 3 (Vienna, 1781), 335.

$81 \quad$ Ibid.

82 Dimitrie Tुichindeal, Îndreptări moraliceşti tinerilor foarte folositoare (Moral Guidelines of Great Benefit to the Youth) (Buda, 1813), 62. Dimitrie Tुichindeal (1775-1818) was a Romanian teacher and priest from the Banat who translated or wrote many manuals of savoir-vivre.

83 Sulzer, Geschichte, III: 334.

84 Ibid. See also the episodes analyzed by Dariusz Kołodziejczyk, "Semiotics of Behavior in Early Modern Diplomacy: Polish Embassies in Istanbul and Bahçesaray," Journal of Early Modern History 7 , no. 3-4 (2003): 245-256. 
All the same, it must be observed that the term ypolipsis does not completely correspond to the term politie (civility) as it was expressed in Romanian at the time ${ }^{85}$ Civility includes a "code of refined manners, the practices of polite behavior." 86 From Erasmus onward, via Antoine de Courtin, Jean-Batiste La Salle, and L.-M. Herriquez, practices were constructed that regulated the behavior of the individual in society: "legitimate behaviors" necessary for common life and the promotion of decency. All these treatises were directed principally at the education of children, and their use in schools was recommended, as civility was incorporated among the Christian virtues. ${ }^{87} \mathrm{~A}$ "virtue of society," civility has the role of making the connections pleasant between people. ${ }^{8}$ Politíe (civility) and ypolipsis are expressed by the same references to honor, prestige, and consideration but without covering the same meaning. Ianache Văcărescu was mainly interested in social distinction, inscribing himself in a logic of prestige, by working on appearances. ${ }^{89}$ Vestimentary opulence and "subtle spirit" (brilliant and educated intelligence) provided him with the consideration and self-esteem that are indispensable for dominating the political stage.

\section{Far from Vienna}

While waiting for his sons, who had wandered off to discover Europe, Alexandros Ypsilantis resigned his mandate for fear of losing his head. As the boys did not stop in Vienna, instead making a short trip through Italy before embarking for Constantinople, there was nothing their father could do but pay the massive debts they had left behind them. ${ }^{90}$

As for Ianache Văcărescu, he remained faithful to the Ottoman Empire but not to the new Phanariot ruler, Nicholas Mavrogenis (1786-179o). Mavrogenis's

85 Politie comes from polis and adds the modern sense of "polite."

86 Roger Chartier, Lecturi şi cititori în Franţa Vechiului Regim (Books and readers in Ancien Regime France) (Bucharest, 1997), 57-59.

87 Ibid., 79 .

88 Ibid., 81.

89 Norbert Elias, La société de cour (Paris, 1985), 115.

9o Emperor Joseph II respected the promise he had made to the Wallachian office-holder. The young Constantine and Dimitrios Ypsilantis were well received at the court of Vienna, but they were urged to return home. See the diplomatic correspondence in this aspect in HHStA, Türkei, II/77, ff. 152-155. Hurmuzaki, vol. 7: 333-334, 361-363, 377-378, 441-442; and 9: 124 . 
appointment to the Wallachian throne constituted for Văcărescu an opportunity to express his admiration and allegiance to the Phanariot network: "[Mavrogenis] was not a man who had grown up in the Phanar, so that he would have known the rules of the Phanar, or those of the Sublime Porte." Moreover, a good candidate for the Wallachian throne should be familiar with the "custom of the land" and possess the linguistic skills necessary for interacting with multiple centers of power. However, Mavrogenis was ignorant of the customs, "he spoke neither Greek or Turkish," and "was even unable to master Romanian throughout his life." ${ }^{11}$ Hence, Văcărescu despised him for his lack of education and for the fact that he did not belong to the Phanariot elite, being a mere ship's captain-in other words, "a man foolish in his behavior, his thinking, and his feelings."92

Believing in the supremacy of the Sublime Porte, he refused to follow Mavrogenis in the war of 1787-179o, and ended up going into exile first in Nikopol (Ottoman Niğbolu) and then on Rhodes. ${ }^{93}$ It was in Nikopol, in 1788 , that he began work on what would become his History of the Most Powerful Ottoman Emperors.

The memoirs of the Wallachian office-holder contain important information about the role of mediator that he assumed in various social, political, religious, and linguistic contexts. ${ }^{94}$ In writing about the Ottoman Empire and serving the Ottoman Empire, ${ }^{95}$ Ianache Văcărescu was one of those intermediaries who participated in the production and dissemination of a literature about the Ottomans in Europe. The knowledge accumulated by Ianache Văcărescu came from his interactions with scholars from the three empires on the borders of Wallachia. His book (together with numerous reports) responded to an already existing curiosity about all that came out of the Ottoman Empire. In gathering information and putting it into circulation, integrating himself in the diplomatic sociability of the Ottoman Empire, Ianache was an important actor, straddling cultural and linguistic borders and contributing to the field of knowledge about the Ottomans. At the same time, Ianache Văcărescu modeled

91 Văcărescu, Istoria Othomanicească, 142.

92 Ibid.

93 HHStA Moldau-Walachei I/26, f. 74-75, March 10, 1791.

94 See the chronicle of events in Wallachia narrated by another boyar, one close to Ianache Văcărescu, Ban Mihai Cantacuzino, who in 1778, after several attempts by his brother Pârvu Cantacuzino to become ruling prince, chose to leave for Russia: Mihai ban Cantacuzino Genealogia Cantacuzinilor (Genealogy of the Cantacuzinos), ed. Nicolae Iorga (Bucharest, 1902).

95 In his view, the mission to bring back Ypsilantis' sons was "a service rendered to the [Ottoman] Empire," Văcărescu, Istoria Othomanicească, 127. 
his education and career according to the requirements of the Ottoman imperial system, adopting "the service and culture of the Phanariots." ${ }^{\text {96 }}$ In turn, the Phanariot elite integrated him into its own networks by means of marital alliance and employed him for numerous diplomatic and political missions.

\section{Acknowledgements}

My special thanks for the English translation of this study are addressed to Dr. James Christian Brown (University of Bucharest). This study was supported by the project Luxury, Fashion and Social Status in Early Modern South-Eastern Europe (LuxFaSS), with number ERC-2014-CoG no. 646489, financed by the European Research Council and hosted by New Europe College, Bucharest.

$96 \quad$ Philliou, Biography of an Empire, 39. 